\title{
KUALITAS PELAYANAN PARKIR DI TEPI JALAN UMUM \\ KOTA YOGYAKARTA
}

\author{
Abdiana Ilosa ${ }^{1}$
}

\begin{abstract}
Starting in 2010 the Government of Yogyakarta, according to regional regulation about parking and levy on the edge of public street parking. This policy expected to increase parking levy's revenues, more secure services and convenient parking, and traffic flows smoothly. This research used qualitative descriptive method. This research analyzed qualitative indicators of quality of service: 1) tangible 2) reliability; 3) transaparant and 4) security. This research found that public street parking less well and yet according to the wishes of the community. This is because the layout of the parking spaces are not in place that interfere with the capacity of highways and disrupting the pedestrian capacity. Then the rates charged by parking operator which do not comply with official rates. Human resources of Transportastion Department that monitor directly into the field just a pick up that add up to 12 people to keep an eye on the parking lot 900 people outside the parking operators so ineffective, so that a parking lot of cheating.
\end{abstract}

Keywords: Parking Service Quality, Parking Space, Lack of Human Resource.

\begin{abstract}
ABSTRAK
Mulai tahun 2010 Pemerintah Kota Yogyakarta, sesuai Perda Perparkiran dan Perda Retribusi Parkir Tepi Jalan, memberlakukan kenaikan tarif parkir untuk semua jenis kendaraan, menyederhanakan kawasan, dan menambah porsi bagi hasil pungutan retribusi parkir kepada juru parkir. Penelitian ini meneliti bagaimana kualitas parkir di tepi jalan umum Kota Yogyakarta. Penelitian ini menggunakan metode deskriptif kualitatif. Analisa dengan indikator kualitas pelayanan: 1). tangible (bentuk fisik); 2). Rability (keandalan); 3). Transaparan (kejelasan dan kepastian); dan security (jaminan keamanan). Hasil analisis menunjukkan bahwa kualitas pelayanan parkir di tepi jalan umum Kota Yogyakarta kurang baik dan belum sesuai dengan keinginan masyarakat secara ideal. Hal ini karena letak ruang parkir yang tidak pada tempatnya yang mengganggu kapasitas jalan raya dan mengganggu kapasitas pejalan kaki. Kemudian tarif yang dipungut oleh petugas parkir yang tidak sesuai dengan tarif resmi. Kemudian SDM dinas perhubungan yang kurang dan banyak pelanggaran parkir oleh juru parkir.
\end{abstract}

Kata kunci: Kualitas pelayan parkir, parkir TJU, SDM kurang.

\footnotetext{
1 Dosen, Jurusan Ilmu Administrasi Negara, Universitas Islam Negeri Sultan Syarif Kasim. email: ella.abdiana@yahoo.com
} 


\section{PENDAHULUAN}

Parkir merupakan suatu kebutuhan bagi pemilik kendaraan yang menginginkan kendaraannya dapat parkir di tempat yang mudah dicapai, salah satunya adalah di tepi jalan umum. Parkir di tepi jalan adalah parkir yang berada pada badan jalan. Maka, jenis parkir ini dapat mengakibatkan turunnya kapasitas jalan karena mangambil bagian dari jalan sehingga badan jalan menjadi sempit. Seiring berjalannya waktu, ruang parkir yang disediakan oleh pemerintah sangat minim jumlahnya untuk menampung kendaraan bermotor yang kian tahun kian bertambah. Kemudian masyarakat menggunakan ruang yang kosong untuk parkir, maka jalan raya tidak dilewatkan untuk dijadikan tempat parkir. Dengan dihadirkannya jalan raya sebagai tempat parkir, maka akan timbul banyak masalah, mulai dari kelancaran lalu lintas yang terganggu hingga menimbulkan kesembawutan kota. Ada beberapa hal menarik mengenai perparkiran ini yaitu:

1. Perparkiran dijalan umum menjanjikan kontribusi yang cukup besar bagi daerah otonomi.

2. Perparkiran di jalan umum di lain pihak dapat mengganggu kelancaran lalu lintas
3. Munculnya parkir liar, juru parkir gadungan dan premanisme. Timbulnya parkir liar ini tidak terbatas pada acara-acara insidental, tetapi merambah tempat-tempat ramai pengunjung, seperti pusat pembelanjaan, restoran, cafe, hotel, bahkan di gerai ATM dan warung kaki lima.

4. Karcis parkir seringkali tidak diberikan kepada pengguna parkir, khususnya di tepi jalan umum, ada juru parkir yang curang yaitu yang mengganti karcis dengan kartu yang dibuat sendiri tanpa persetujuan instansi yang berwenang.

Pembinaan dan pengelolaan perparkiran merupakan kegiatan yang dilaksanakan secara terpadu dan terkoordinasi di daerah. Hal ini dilakukan untuk menjamin terselenggaranya pembinaan yang berhasil mewujudkan penataan lingkungan perkotaan, kelancaran berlalu lintas ketertiban administrasi pendapatan daerah, serta mampu mengurangi beban sosial melalui penyerapan tenaga kerja (SK Menhub No 34 tahun 1990). Pemerintah daerah mempunyai tugas dan tanggungjawab 
dalam membinaan pengelolaan parkir di wilayahnya, yang merupakan bagian dari fungsi pelayanan umum. Sebagai imbalan penyelenggaraan pelayann umum, pemerintah baik berhak memungut dana dari masayarakat dalam bentuk retribusi dan pajak sebagai salah satu sumber PAD (Direktorat Jendral Perhubungan Darat, 1998). Untuk parkir baik itu parkir umum atau parkir khusus, diperlukan adanya ketentuan-ketentuan bagi pemerintah dan pengelola dalam kegiatan perencanaan, pengaturan, pengawasan dan pengendalian tempat parkir sehingga dapat dijadikan sebagai salah satu sumber penerimaan daerah yang potensial guna mendukung jalannya pemerintah dan kelancaran pembangunan kota.

Adanya perubahan-perubahan yang terjadi dalam masyarakat, baik dalam demografi, ekonomi maupun sosial mempunyai implikasi tertentu kepada sektor parkir. Peningkatan jumlah kendaraan bermotor menimbulkan persoalan lalu lintas dan mempengaruhi kegiatan perparkiran.

$$
\text { Dalam mengatasi masalah }
$$
transportasi ada beraneka ragam instrumen kebijakan yang dapat digunakan oleh pemerintah. Instrumen yang umum dikenal adalah peraturan atau regulasii, perizinan lokasi parkir dan pemberlakuan dan pengendalian harga.Pemerintah kota Yogyakarta memilih menggunakan instrumen regulasi sebagai saran untuk mengendalikan dan mengelola sektor parkir. Untuk alasan mewujudkan penataan perparkiran yang lebih efektif dan efisien sehingga dapat mendukung kelancaran lalu lintas dan peningkatan pelayanan kepada masyarakat pengguna jasa parkir secara lebih baik. Pemerintahan kota Yogyakarta memberlakukan peraturan daerah (Perda) No 19 tahun 2009 tentang retribusi parkir tepi jalan umum dan Perda No18 tahun 2009 tentang penyelenggaraan perparkiran. Salah satu implikasi pemberlakuan Perda No18 tahun 2009 bagi masyarakat pengguna jasa parkir adalah kenaikan tarif parkir sebesar 100 $\%$. Kemudian dikeluarkan Peraturan Daerah Kota Yogyakarta No 5 tahun 2012 Tentang Retribusi jasa umum merubah tarif parkir menjadi sama antara kawasan I dan kawasan II.

Tentang kondisi dan kebijakan perparkiran di Kota Yogyakarta, pakar dari Pusat Studi Transportasi dan Logistik Universitas Gadjah Mada, Heru Sutomo menilai Pemkot Yogyakarta tidak mempunyai konsep dalam mengelola parkir. Peraturan daerah yang muncul 
lebih banyak menyoroti masalah tarif, bukan wilayah mana saja yang bisa dijadikan lahan parkir dan peningkatan pelayanan publik. Padahal, masalah pokoknya adalah kemunculan tukang atau juru parkir di lahan parkir yang ilegal dan fenomena preman perparkiran yang diduga dimanfaatkan pemerintah mendongkrak target setoran retribusi. Kondisi sepeti ini menyebabkan kenyamanan para pengguna parkir terganggu. Dan kualitas pelayanan yang diberikan oleh Pemerintah Daerah tentang perparkiran jadi tidak efisien.

Melihat keadaan perparkiran tepi jalan sekarang di Kota Yogyakarta mempunyai masalah yang sangat banyak diantaranya dari hasil observasi awal penulis menemukan fenomena dimana sepanjang Jalan Maliboro banyak petugas parkir yang tidak memberikan karcis parkir malah mereka yang memberikan karcis parkir selalu meminta kembali parkir kepada pengguna parkir setelah mengambil kendaraannya, kemudian mulai jam 5 sore petugas parkir menaikkan tarif parkir menjadi 2 kali lipat dari harga karcis, alasannya pergantian petugas parkir padahal Jalan Malioboro itu adalah kawasan I, dan Jalan Malioboro adalah kawasan ramai tujuan para wisatawan.
Yang menarik dengan setoran juru parkir yang tidak sepenuhnya didasarkan atas perhitungan karcis, target pendapatan parkir di tepi jalan umum di Kota Yogyakarta tiap tahun selalu tercapai. Peran efektif koordinator wilayah (korwil) dalam pelaksanaan operasional pemungutan retribusi parkir sesuai dengan wilayah tugasnya dan tugas-tugas administrasi dan keuangan terkait dengan pemungutan retribusi parkir, ikut menentukan tercapainya target pendapatan parkir. Ini berbeda dengan temuan di daerah lain, seperti Kota Semarang misalnya, dimana ditemukan koordinator wilayah menjadi salah satu penyebab tidak terealisasinya target pendapatan karena tidak menyetor ke Unit Pengelolaan Perparkiran.

Beberapa kejadian tersebut menimbulkan tanda tanya terkait kualitas kebijakan perparkiran di Kota Yogyakarta, kejelasan tarif dan perasaan aman dan nyaman bagi pengguna parkir. Padahal, salah satu konsideran Perda Perparkiran dan Perda Retribusi Parkir di Tepi Jalan Umum secara jelas mengusung pelayanan perparkiran yang berorientasi kenyamanan dan keamanan bagi pengguna jasa perparkiran. Dengan banyaknya juru parkir yang beroperasi di ruas-ruas jalan Kota Yogyakarta sekarang 
saja, sudah mulai dirasakan adanya permasalahan transportasi seperti seringnya kita melihat lalu-lalang kendaraan bermotor yang memadati jalanan, kemacetan di berbagai ruas jalan yang diakibatkan parkir yang semrawut yang berpotensi mendatangkan kecelakaan. Ada yang mengatakan sebagian masalah tersebut diakibatkan oleh parkir-parkir liar di ruas-ruas jalan (Kompas Yogyakarta, 9/02/2010). Guna mengatasi permasalahan di atas, Pemerintah Kota Yogyakarta memberlakukan Perda No. 18 Tahun 2009 tentang Perparkiran dan Perda No. 19 Tahun 2009 tentang Retribusi Parkir Tepi Jalan Umum, menggantikan regulasi lama yang dirasakan sudah tidak sesuai lagi dengan kondisi saat ini.

\section{Berdasarkan latar belakang} tersebut, dapat dilihat permasalahan nya disini adalah masalah perparkiran tepi jalan Kota Yogyakarta masih mempunyai masalah bagi pemerintah yang berkaitan dengan pemasukan PAD dan untuk pelanggan atau masyarakat pada penerapannya dilapangan masyarakat masih mengeluh masalah pelayanan parkir yang diberikan. Untuk itu penulis memandang perlunya melakukan analisis kualitas pelayanan parkir tepi jalan Kota
Yogyakarta berdasarkan persepsi pelanggan dan pengelola parkir.

\section{METODE}

Metode yang digunakan dalam penelitian ini adalah metode penelitian deskriptif kualitatif. Peneliti dalam hal ini mendeskripsikan tentang bagaimana kualitas pelayanan parkir di tepi jalan umum Kota Yogyakarta dengan cara mewawancarai beberapa orang yang ditemui di tempat parkir yang memakai jasa parkir ditempat tersebut selama peneliti melakukan penelitian. Kemudian peneliti juga mendeskripsikan faktorfaktor apa saja yang mempengaruhi kualitas parkir dengan cara melakukan wawancara mendalam kepada petugas dinas perhubungan dan juru parkirdan kemudian mengambil kesimpulan tentang kualitas pelayanan parkir tersebut.

\section{HASIL DAN PEMBAHASAN}

\section{Kualitas Pelayanan Parkir di Tepi Jalan Umum Kota Yogyakarta}

Data utama dari kualitas pelayanan parkir tepi jalan adalah penilaian pengguana jasa parkir atau masyarakat. Selain itu juga dengan cara mengecek 
laporan dari dokumen organisasi mengenai pelayanan yang diberikan. Untuk mengetahui apakah dinas perhubungan bidang perparkiran dan sebagai pelaksana juru parkir telah memberikan pelayanan yang berkualitas yaitu pelayanan yang sesuai dengan harapan masyarakat, sehingga masyarakat merasakan adanya kepuasan atas pelayanan tersebut maka akan diukur dari tiga sisi yaitu masyarakat, aparat pemerintah bidang perparkiran dan juru parkir. Indikator yang digunakan untuk mengukur kualitas pelayanan parkir tepi jalan umum Kota Yogyakarta adalah:

\section{Bentuk Fisik (Tangible)}

Salah satu indikator dalam memperoleh kualitas pelayanan parkir adalah bentuk fisik (tangible) yaitu letak ruang parkir dengan fasilitas dan peralatannya yang lengkap untuk kenyamanan pengguna parkir. Kualitas pelayanan parkir tepi jalan umum (TJU) yang selanjutnya disingkat dengan TJU akan dinilai baik apabila failitas dan letak tempat parkir yang memenuhi kehendak masyarakat dan melebihi keinginan masyarakat. Peraturan Daerah Kota Yogyakarta No 18 tahun 2009 tentang Penyelenggaraan Perparkiran Pasal 3 ayat (1) menyatakan bahwa penetapan kawasan dan lokasi tempat parkir dengan memperhatikan, rencana tata ruang kota, keselamatan dan kelancaran lalu lintas, penataan dan kelestarian lingkungan, kemudahan bagi tempat parkir

Peraturan Walikota (Perwali) Kota Yogyakarta No. 112 Tahun 2009 Pasal 2 ayat (1) menyatakan bahwa setiap ruas jalan yang ditetapkan sebagai lokasi tempat parkir, dinyatakan dengan rambu parkir, dan atau marka parkir. Lokasi parkir sendiri dibedakan menjadi 2 (dua) kawasan, yaitu kawasan I dan kawasan II. Untuk ruas-ruas jalan yang termasuk kategori kawasan II, sesuai Pasal 2 ayat (4) Perwali No. 12 Tahun 2009, meliputi seluruh ruas jalan yang tidak termasuk dalam kawasan I di atas dalam wilayah administrasi kota Yogyakarta. Dalam praktek pelaksanaannya, parkir TJU Kota Yogyakarta terdapat suatu permasalahan yaitu parkir TJU mengakibatkan kemacetan jalan, padahal dalam Peraturan Daerah Kota Yogyakarta Nomor 18 Tahun 2009 menerangkan kalau tempat parkir harus memperhatikan keselamatan dan kelancaran lalu lintas.

Berdasarkan observasi awal, penulis menemukan di sekitar Jalan Mayor Suryotomo, Jalan Sudirman ke arah Tugu, Jalan Diponegoro sampai 
persimpangan Jalan Bumijo dan Jalan Asem Gede, kemudian Jalan Urip Sumoharjo sampai perempatan Galeria, dan Jalan Mataram mengalami kemacetan pada jam-jam sibuk dan musim liburan. Di Jalan Urip Sumoharjo, parkir berlaku di dua sisi ruas jalan dengan pola parkir menyudut. Walaupun arus lalu lintas satu arah ke barat, dengan aktivitas bisnis di sepanjang pertokoan dengan volume parkir yang tinggi menyebabkan kelambatan kecepatan kendaraan menuju Jalan Sudirman. Jalan Mayor Suryotomo, dekat toko Progo dan sepanjang pertokoan belakang Pasar Beringharjo, dengan arus lalu lintas dua arah, adalah ruas jalan yang sering mengalami kemacetan. Parkir di dua sisi jalan ikut menambah kemacetan dan memperlambat laju kendaraan. Selain itu terlihat adanya keluhan dari sebagian masyarakat sebagai pengguna jalan raya:

"tiap pulang kantor saya selalu terjebak macet di jalan ini, yang sering bikin saya kesal adalah macetnya gara-gara parkir kendaraan di tepi jalan apalagi kalau di sebelah kiri ada motor parkir dan sebelah kanan parkir mobil, padahal ini adalah parkir satu arah, tapi kalau mau protes gak tau kemana ya saya terima saja (wawancara tanggal di sayap Jalan Urip Sumuharjo dengan Mbak Lilik, pegawai swasta)"
Ungkapan yang serupa juga oleh Bapak Suparno seorang PNS :

"Di daerah ini memang selalu macet, saya rasa kemacetan ini karena letak parkir tepi jalan yang mengambil badan jalan, sementara jalan ini bisa dikategorikan jalan kecil yang seharusnya tidak dibagi lagi untuk parkir di tepi jalan, belum lagi parkir tepi jalan ini sangat dekat lampu merah (persimpangan), hal ini juga bisa menyebabkan kemungkinan terjadinya kecelakaan"

Pasal 43 UU LLAJ No. 22 Tahun 2009 j.o. Keputusan Dirjen Perhubungan Darat No. 272/HK.105/DRJD/96 tentang Pedoman Teknis Penyelenggaraan Fasilitas Parkir menyatakan bahwa terdapat beberapa tempat pada ruas jalan yang tidak boleh untuk tempat berhenti atau parkir kendaraan. Dari penuturan informan diatas dan juga survey penulis dapat dilihat bahwa letak parkir pada jalan Rahayu Samirono menyalahi UU LLAJ No. 22 Tahun 2009 dimana letak parkir TJU nya kurang dari 25 meter $\mathrm{dr}$ persimpangan. Parkir di jembatan sayidan salah karna kurang dari 50 meter sebelum dan sesudah jembatan. Kemudian petugas parkir memakai rompi parkir resmi dari dinas perhubungan.

Selain keluhan masyarakat tentang kemacetan yang diakibatkan parkir TJU 
dan letak parkir TJU yang tidak sesuai dengan Pedoman Teknis Penyelenggaraan Fasilitas Parkir oleh LLAJ juga ditemui adanya parkir ilegal yang dapat mengurangi kenyamanan pejalan kaki dan juga menyebabkan kemacetan. Hasil observasi penulis parkir di dua sisi Jalan Suryopratomo, meskipun paralel, memang paling terlihat mempersempit badan jalan sehingga turut menyebabkan kemacetan. Apalagi volume/arus lalu lintas disana sangat tinggi. Tanpa median jalan seperti saat ini, dengan dua arus lalu lintas berlawanan, bisa dipastikan ruas jalan tersebut mengalami kemacetan yang parah. Di dua ujung jalan itu terdapat perempatan jalan yang membuat lalu lintas bergerak lamban dan tidak bergerak sama sekali pada jam-jam sibuk.

Penulis mengamati juru parkir di depan Toko Progo berbeda dengan juru parkir di ruas-ruas jalan karena juru parkir disana tidak menggunakan seragam resmi yang dikeluarkan Dinas Perhubungan dan tidak menggunakan karcis. Yang paling mencolok adalah di tempat parkir berdiri rambu larangan parkir. Parkir di tepi jalan umum jika tidak ditata secara baik akan menyebabkan juru parkir tidak terkontrol sehingga parkir TJU bermunculan dimana-mana tanpa diawali satu kelayakan yang standar. Apalagi ditambah dengan keberadaan pedagang kaki lima atau sektor informal di trotoar atau ruang milik jalan (right of way) yang mengundang konsumen untuk parkir, ikut menambah tingkat kemacetan.

Masalah kebersihan, kerapian dan kelengkapan tempat parkir, parkir TJU Kota Yogyakarta menurut hasil survei penulis tergolong bersih dan rapi. Namun, dalam kenyataannya sekarang ini tong sampah yang disediakan oleh dinas pehubungan sudah jarang ditemukan. Hasil survei penulis melihat tong sampah yang disediakan di ruang parkir hanya di daerah malioboro dan itu juga sangat sedikit. Dan pohon yang berfungsi memperindah ruang parkir beralih fungsi menjadi tempat sampah karena di dekat situ tidak ada tong sampah, maka pengguna atau pejalan kaki membuang sampah dalam pot bunga tersebut

\section{Keandalan (Reability)}

Dalam melayani kebutuhan dari pengguna jasa maka kemampuan aparat yang bertugas dalam hal pelayanan menjadi sangat penting. Demikian juga halnya dengan Juru parkir sebagai pelaksana kebijakan dan yang memberikan pelayanan langsung kepada pengguna parkir, juru parkir dan aparat pemerintah (Dinas Perhubungan) 
merupakan ujung tombak dalam bidang pelayanan parkir TJU. Dalam konteks kualitas pelayanan parkir di tepi jalan umum (TJU) di Kota Yogyakarta, aktor kunci yang berperan cukup besar tak dapat dipungkiri, adalah Juru Parkir. Juru Parkir, seperti yang terbaca dari Perda No. 18 dan No. 19 Tahun 2009, adalah ujung tombak yang menentukan berhasil-tidaknya tujuan kebijakan parkir (policy goals), yakni mewujudkan kelancaran lalu lintas dan kepuasan pengguna jasa parkir.

Untuk menciptakan kualitas pelayanan yang diinginkan masyarakat, juru parkir sebagai perpanjangan tangan dinas perhubungan dalam melaksanakan pelayanan yang langsung bertatap muka dengan pengguna layanan yaitu pengguna parkir tidak hanya memfokuskan kepada kendaraan yang diparkir atau meminta tarif parkir tapi juga harus memperhatikan kesopanan, keramahana, kenadalan dalam melaksanakan tugasnya. Keramahan memang satu kata yang cukup singkat namun memiliki dampak yang sangat penting bagi masyarakat yang menggunakan pelayanan. Keramahan merupakan suatu sikap yang mau tidak mau harus melekat dalam diri pelayanan. Tindak tanduk pegawai pelayanan sering menjadi bahan perhatian masyarakat. Keramahan petugas parkir akan dilihat mulai dari pengguna layanan parkir memasukkan kendaraannya ke dalam ruang parkir sampai kendaraan itu diambil kembali.

Yogyakarta sebagai Kota Wisata dan kota pendidikan yang bermoto "Yogyakarta berhati nyaman" juru parkir juga harus menunjukkan kalau mereka ramah kepada pelanggannya walaupun kerja dibawah sinar matahari, tapi pada kenyataannya banyak ditemui petugas parkir yang hanya memberikan karcis dan ketika pengambilan motor mengambil bayaran, tanpa melontarkan sedikit senyum kepada pengguna parkir, seperti penuturan Mas Damaris warga Kasihan Bantul:

"petugas parkir disini terkesan minimalis dan pelit senyuman mbak. Ia mengeluh ketika parkir sedang ramai,setelah membayar, ditinggal juru parkir begitu saja dan harus mengambil sendiri Motor kita yang sedang dalam posisi terjepit kendaraan lain, sedangkan juru parkir sendiri sibuk memungut retribusi pengguna parkir yang lain. Padahal saya sudah membayar Rp. 1000"

3. Kejelasan dan kepastian (transparansi)

Pelayanan parkir harus transparan dalam hal tarif karena retribusi parkir pembayarannya langsung diberikan 
kepada pihak pemberi pelayanan dan juga pelayanan nya langsung didapat oleh pengguna layanan. Dalam kasus tarif perparkiran banyak sekali ditemui masalah, salah satunya pengaduan yang dikirim ke UPIK (unit pelayanan informasi keluahan). Ketika penulis melakukan penelitian hampir semua informan mengeluhkan dan punya masalah dengan tarif parkir di tepi jalan umum Kota Yogyakarta.

Bukan hanya masalah tarif tapi banyak dari juru parkir yang tidak memberikan karcis. Selama penelitian, peneliti mendapati jalan-jalan yang tidak diberi karcis diantaranya Jalan Mataram, Jalan Mangkubumi, Jalan C Simanjuntak, Jalan Cik Ditiro, Jalan Abu Bakar Ali, jalan P. Mangkubumi dan masih banyak yang lain. Yang pasti memakai karcis diantaranya Jalan Malioboro, Jalan Urib Sumoharjo (Jalan Solo) dan lain-lain. Berdasarkan ketentuan, pengguna parkir yang tidak mematuhi tanda parkir dalam bentuk rambu atau marka, tidak meminta karcis parkir resmi dan tidak menunjukkan karcis ketika mengambil kendaraan dan membayar, dapat diartikan melanggar ketentuan ini. Hal itu berarti, kesalahan ada pada pengguna parkir ketika memarkir kendaraan di lokasi yang jelas-jelas terpampang rambu larangan parkir, seperti yang terjadi di depan toko Progo. Pasal 25 ayat (1) Perda Perparkiran mengancam pidana kurungan paling lama 3 bulan atau denda Rp. 50 juta terhadap pelanggaran Pasal 20a ini. Praktiknya hingga hari ini tidak ada satupun pengguna parkir dipidanakan karena memarkir kendaraan di lokasi terlarang.

Mengacu pada ketentuan tadi, sesungguhnya kesalahan terletak pada pengguna parkir ketika tidak meminta karcis parkir resmi kepada juru parkir. Namun, tidak ada ketentuan yang mengatur sanksi untuk pelanggaran itu. Perda ini sebenarnya sudah mengantisipasi kejadian seperti pemakaian karcis berulang dan kengganan juru parkir memberi karcis dengan mewajibkan pengguna parkir bertindak aktif meminta karcis parkir. Menurut Perda Perparkiran, pemungutan retribusi dilakukan dengan cara juru parkir menyerahkan karcis parkir sebagai tanda bukti untuk setiap kali parkir pada saat memasuki lokasi parkir dan memungut retribusi sesuai dengan jenis kendaraan dan kawasan. Selain itu, sesuai dengan Pasal 5 Perda Perparkiran, karcis parkir resmi yang dipakai sebagai tanda bukti parkir digunakan untuk satu kali parkir dan tidak boleh digunakan lebih dari satu kali. Jika juru parkir kedapatan memakai 
karcis lebih dari satu kali, Dinas Perhubungan, sesuai Pasal 23 Perda Perparkiran, akan mencabut Surat Tugas juru parkir tersebut. Sesuai Pasal 25 ayat (1) Perda Perparkiran, juru parkir tersebut diancam pidana kurungan paling lama 3 bulan atau denda Rp. 50 juta. Dari hasil wawancara yang menjadi pertanyaan dan yang menjadi masalah adalah fungsi juru parkir sebenarnya. Fungsi juru parkir menurut Perda Kota Yogyakarta No 18 tahun 2009 tentang penyelenggaraan perparkiran fungsi juru parkir adalah menjaga kemanan dan ketertiban tempat parkir (memarkirkan kendaraan pada tempat yang telah ditentukan).

\section{Jaminan keamanan (security)}

Untuk menciptakan kualiatas pelayanan parkir yang baik maka sebagai pengguna parkir harus bisa merasa percaya akan keamanan kendaraan mereka yang sedang diparkirkan. Petugas parkir harus bisa memberikan jaminan kepada pengguna parkir bahwa kendaraan yang akan mereka parkir aman dan dan tidak menggagu kelancaran lalu lintas juga memberikan ganti rugi atas kerusakan atau kehilangan barang yang ada di kendaraan mulai dari helm, aksesors kendaraan, atau apabila terjadi kecelakan pada kendaraan sekalipun itu lecet pada kendaraan.

Hak-hak pengguna jasa parkir secara implisit terbaca dari ketentuan Pasal 5 Perda Perparkiran yang mengatur kewajiban juru parkir, yakni memperoleh rasa aman atas kendaraan beserta perlengkapannya dan memperoleh karcis sebagai tanda bukti parkir. Untuk kasus kehilangan, hanya diatur kehilangan kendaraan, bukan perlengkapan atau barang-barang yang ditaruh di kendaraan. Pasal 17 Perda Perparkiran menentukan ganti rugi atas kehilangan kendaraan pada saat parkir di tempat parkir maksimal sebesar 50 persen yang ditanggung oleh juru parkir. Walaupun sudah ada peraturan resmi yang mengatur mengenai hak pengguna jasa parkir mendapatkan rasa aman atas kendaraan beserta perlengkapannya tetapi tetap pengguan parkir di tepi jalan umum Kota Yogyakarta kurang merasa aman seperti penuturan Mbak Fitri:

\footnotetext{
"mbak lihat sendiri kan betapa mepetnyaparkir-parkir disini saya jadi was was takutnya motor saya kegores soalnya itu terlalu dekat jarak antara satu motor dengan motor lain. Kalau masalah kehilangan motor saya tidak takut mbak, tapi ya itu dia yang bikin saya gak nyaman gara-gara letak motor yang terlalu rapat"
} 
Setelah di konfirmasi masalah diatas kepada petugas parkir Bapak Sarjono mengungkapkan:

"kalau masalah kehilangan jangan khawatir mbak, kita petugas parkir selalu ada ditempat kok, nan kalaupun ada orang yang mau ambil motor dia wajim melihatkan karcis dan kita kan mengecek kesesuaian dengan karcis yang ditempel di motor kalau tidak sesuai kita akan minta STNK, kalau masalah barang ada yang hilang kita belum pernah mendapatkan pengaduan dari pengguna parkir masalah kerusakan juga belum pernah ada mbak"

Kalaupun ada yang melapor proses ganti rugi sudah diatur dalam Peraturan Daerah No 18 tahun 2009 Pasal 17 ayat (2) mengatur Ganti rugi apabila terjadi kerusakan atau kehilangan kendaraan diselesaikan secara musyawarah, tidak langsung dibawa ke proses hukum. Cara ganti rugi menurut pasal 17 PerDa No 18 tahun 2009 adalah:

a. Apabila terjadi kehilangan atau kerusakan kendaraan pada saat parkir di tempat parkirTepi Jalan Umum, menjadi tanggungjawab juru parkir;

b. Pengguna jasa parkir yang kehilangan atau kerusakan kendaraannya pada saat parkir di tempat parkir diselesaikan secara musyawarah;

c. Ganti rugi yang menjadi tanggungjawab juru parkir sebagaimana dimaksud pada ayat (1) ditetapkan sebesar 50\% (lima puluh perseratus);

d. Pemerintah daerah dalam rangka memberikan perlindungan terhadap pengguna jasa parkir, dapat melibatkan asuransi parkir sesuai kemampuan keuangan daerah;

e. Tatacara dan mekanisme penyelesaian ganti rugi diatur lebih lanjut dengan Peraturan Walikota.

Dari ke empat indikator diatas (tangible, reability, kejelasan, transparansi dan security) maka penulis menyimpukan bahwa kualitas pelayanan parkir di tepi jalan umum Kota Yogyakarta kurang baik hal ini karena banyaknya keluhan masyarakat. Sedangkan baik tidaknya kualitas sebuah pelayanan itu diukur dari tingkat kepuasan masyarakat, pelayanan itu akan baik apabila pelayanan yang diberikan melebihi keinginan masyarakat. Dan dari ke empat faktor diatas yang paling banyak dikeluhkan oleh masyarakat adalah letak ruang parkir yang 
menyebabkan kemacetan dan juga tarif yang tidak sesuai. Hal ini juga dapat dilihat dari jumlah pengaduan Pada UPIK (Unit Pelayanan Informasi Keluhan) dimana yang paling banyak itu pada masalah letak parkir yang menggangu lalu lintas serta tarif yang tidak sesuai.

\section{Faktor-Faktor yang Mempengaruhi Kualitas Pelayanan Parkir di Tepi Jalan Umum Kota Yogyakarta}

Dalam menjelaskan faktor-faktor yang dapat mempengaruhi kualitas pelayanan parkir tepi jalan umum Kota Yogyakarta perlu mengetahui faktor pendukung yang menyebabkan keberhasilan atu kegagalan suatu organisasi dalam memberikan pelayanan publik yang berkualitas. Faktor tersebut akan muncul baik didalam maupun diluar organisasi. Kuliatas pelayanan publik yang diberikan oleh birokrasi dipengaruhi oleh berbagai faktor, seperti tingkat kompetensi aparat, kualitas peralatan yang digunakan untuk merespon pelayanan, budaya birokrasi dan sebagainya (Dwiyanto, 2006:142).

Dalam birokrasi publik yang bertanggung jawab memberikan pelayanan publik kepada masyarakat, dan berinteraksi langsung dengan masyarakat hendaklah memperhatikan faktor-faktor yang dapat mempengaruhi kualitas pelayanan publik seperti pada perparkiran tepi jalan umum Kota Yogyakarta. Dinas perhubungan termasuk juru parkir berusaha memberikan pelayanan yang berkualitas kepada masyarakat yang menggunakan layanan parkir di tepi jalan umum Kota Yogyakarta.

\section{Sumber Daya Manusia}

SDM sebagai ujung tombak dalam memberikan pelayanan kepada publik, sumber daya manusia yakni kompetensi aparat pemerintah (dinas perhubungan bidang perparkiran) dengan juru parkir / pembantu juru parkir. Tingkat pendidikan aparatur pemerintah (dinas perhubungan bidang perparkiran) sangat berpengaruh terhadap pelayanan yang diberikan kepada masyarakat. Dinas Perhubungan memiliki cukup sumber daya finansial untuk melaksanakan kebijakan perparkiran di tepi jalan umum. Dari sisi SDM, petugas dinas perhubungan lebih dari separo bergelar sarjana. Muncul kesan, di internal Dinas Perhubungan yang bertanggung jawab dan bekerja mengelola perparkiran hanyalah Bidang Perparkiran. Para pegawai di Dinas Perhubungan rata-rata adalah orang-orang yang mengabdi cukup lama di Dinas Perhubungan. Untuk perparkiran, jumlah SDM cukup banyak, mulai dari Kepala Bidang, Kepala Seksi 
Retribusi Parkir beserta staf, Kepala Seksi Optimalisasi Parkir dan staf-stafnya, Koordinator Wilayah, Juru Pungut yang semuanya PNS, dapat ditambah mitra kerja Pemkot, yakni Juru Parkir yang berjumlah kurang lebih 900 orang namun tidak memiliki ketegasan dalam menjalankan aturan.

\section{Struktur Organisasi}

\section{Dinas Perhubungan Kota Yogyakarta sebagai instansi yang} berwenang menyelenggarakan perparkiran tepi jalan umum, selalu menegaskan sisi pelayanan publik sebagai tujuan utama. Alasannya jelas, tugas utama pemerintah adalah melayani publik, bukan mencari keuntungan (profitoriented). Pernyataan tersebut sesuai dengan teks Perda No. 19 Tahun 2009 Pasal 7 yang menyatakan bahwa prinsip dan sasaran dalam penetapan struktur dan besaran tarif retribusi didasarkan pada tujuan untuk memperlancar lalu lintas dengan tetap memperhatikan biaya penyediaan jasa yang bersangkutan, kemampuan masyarakat dan aspek keadilan.

Pengamatan penulis, struktur birokrasi Bidang Perparkiran sebenarnya cukup sederhana. Rentang kendali dan jalur komunikasi antara Kepala Bidang, Kepala Seksi, Koordinator Wilayah
(Korwil) sampai Juru Pungut tidak rumit dan menghambat dalam merespon permasalahan di lapangan. Yang paling intens berinteraksi dengan juru parkir adalah Korwil dan Juru Pungut. Koordinator wilayah yang ditugaskan dengan Surat Perintah Tugas Kepala Dinas Perhubungan No. 4 Tahun 2010 setiap bulan diharuskan melaporkan perkembangan perparkiran di tepi jalan umum kepada Kepala Dinas melalui Kepala Bidang Perparkiran dan Kepala Seksi Retribusi Parkir. Tetapi, Kepala Bidang dan Kepala Seksi, sangat jarang turun ke lapangan untuk ikut memantau keadaan, seperti penurutan Kasi Retribusi Parkir Imamuddin Aziz Se. Praktis, fungsi pengawasan lebih banyak diperankan oleh koordinator wilayah dan juru pungut yang rutin berkeliling di ruas-ruas jalan sembari melakukan pengecekan setoran dan mengedarkan karcis baru kepada juru parkir.

Ironisnya, peran pengawasan di lapangan masih kurang efektif. Pengawasan yang dilakukan oleh aparatur Bidang Perparkiran masih minim mengingat masih banyak terdapat pelanggaran ketentuan Perda Perparkiran. Birokrat mulai dari Kepala Bidang, Kepala Seksi dan staf-stafnya lebih banyak menghabiskan waktunya di kantor 
ketimbang di lapangan. Padahal, tugas pengawasan melekat pada jabatan mereka. Pengawasan rutin praktis hanya diperankan oleh Koordinator Wilayah dan Juru Pungut yang menjadi bawahannya. Mengawasi ratusan juru parkir, bukan pekerjaan yang mudah dengan jumlah SDM yang sedikit. Perwakilan juru parkir yang dilibatkan sebagai verifikator wilayah dalam Pokja bersama Koordinator Wilayah juga tidak cukup efektif di lapangan. Mungkin ini seperti hasil Liputan Kompas (9/2/2010) disebabkan karena begitu banyaknya "pemain parkir".

Faktor keterbatasan jumlah SDM, menurut Kasi Retribusi, menyebabkan kurang optimalnya implementasi Perda Perparkiran di lapangan, terutama minimnya juru pungut yang melakukan pengawasan rutin. Jumlah juru pungut sekarang 12 orang, ada satu yang merangkap sebagai koordinator wilayah. Mereka kewalahan ketika harus melayani sekaligus mengawasi 900-an juru parkir. Idealnya, menurutnya, satu juru pungut melayani 40-50 juru parkir. Ketika semua juru pungut berkeliling sesuai wilayah masing-masing pun, belum tentu ketemu juru parkirnya. Selain, problem kedisiplinan dan kejujuran juru parkir sendiri yang selalu meminta dispensasi karena menggunakan pendapatan parkir untuk kepentingan pribadi. Ia mengaku bangga, dengan jumlah SDM yang relatif kecil, tahun lalu mampu melebihi target penerimaan retribusi parkir tepi jalan umum, yakni dengan target Rp. 1,47 Milyar, tercapai realisasi Rp. 1,48 milyar.

Dapat dikatakan bahwa rasio sumber daya manusia yang menjalankan fungsi pengawasan perparkiran masih tergolong minim dibandingkan dengan jumlah keseluruhan aparatur Dinas Perhubungan. Akibatnya, koordinator wilayah dan juru pungut tidak mungkin mengawasi satu persatu juru parkir yang berada di wilayahnya. Sehingga logis kalau masih banyak ditemukan pelanggaran ketentuan perparkiran seperti pemakaian karcis berulang, pemungutan tarif yang tidak semestinya, pemakaian karcis buatan sendiri, dan seterusnya. Praktik-praktik itu terkesan seperti ditolerir dan akhirnya menjadi kebiasaan. Dapat dipahami pula bila model patokan lebih efektif dikarenakan sifatnya yang praktis dan tidak menuntut Korwil dan Juru Pungut turun ke lapangan setiap harinya. Terlihat ada semacam hubungan saling percaya (trust) yang terbangun antara koordinator wilayah dengan juru parkir. Jika menghendaki patokan diterima juru parkir, maka koordinator wilayah harus memberikan kebebasan 
kepada juru parkir untuk mendapatkan perolehan retribusi parkir untuk disetor termasuk dengan cara yang mungkin melanggar aturan perparkiran.

Telah disinggung bahwa adanya juru sebagai sebagai pihak yang membantu dinas perhubungan memungut retribusi parkir dan memberikan pelayanan langsung kepada pengguna parkir. Tapi ia tidak masuk dalam struktur organisasi Dinas Perhubungan, meskipun demikian, mereka termasuk bagian dari kepanjangan tangan dinas perhubungan yang mempunyai peran sentral dalam mengimplementasikan kebijakan retribusi parkir di tepi jalan umum pemerintah atau aparatur Dinas Perhubungan tidak mampu melakukan sendiri pemungutan retribusi parkir karena keterbatasan SDM. Juru parkir dalam pemahaman aparatur Dishub, adalah semacam pihak ketiga yang diikat kontrak yang menjual jasanya untuk memungut retribusi dengan imbalan bagi hasil pemasukan retribusi dengan dibekali surat tugas. Karena ia memperoleh delegasi secara resmi dan sah sebagaimana diatur Perda Perparkiran yang juga berfungsi sebagai kontrak pemerintah-juru parkir, secara hukum, ia termasuk bagian dari implementor.
Perda Perparkiran No. 18 Tahun 2009 menyatakan bahwa juru parkir adalah orang yang ditugaskan pada tempat parkir di tepi jalan umum berdasarkan Surat Tugas. Juru Parkir ditugaskan oleh Walikota atau Pejabat yang ditunjuk (dalam hal ini Kepala Dinas Perhubungan) dengan Surat Tugas. Juru Parkir bertanggung jawab kepada Walikota atau Pejabat yang ditunjuk. Kenyataan di lapangan, juru parkir hampir selalu mengalihkan tugas dan tanggung jawab kepada pembantu juru parkir. Administrasi yang buruk di Dinas, ditengarai ikut menyebabkan munculnya fenomena satu juru parkir mempunyai ijin di lebih dari satu lokasi. Akhirnya, yang menjalankan parkir rata-rata bukan juru parkirnya yang memegang ijin, tetapi pembantu juru parkir. Sedangkan juru parkirnya menekuni pekerjaan lain hingga muncul kesan seolah-olah ia berperan sebagai seorang bos.

\section{Sarana dan Prasarana}

Sarana pendukung merupakan salah satu hal yang dapat mempengaruhi kualitas pelayanan pada pelayanan parkir tepi jalan umum Kota Yogyakarta. Karena dengan adanya sarana pendukung pelayanan dapat menunjang pelayanan 
tersebut menjadi lebih baik dan berkualitas. Perlengkapan parkir seperti rambu, marka sangat mempengaruhi kualitas pelayanan parkir hal ini karena dengan kelengkapan parkir maka akan mempermudah pengguna parkir memarkir kendaraannya, dan juga berdampak besar terhadap tata kelola letak parkir agar tidak sembawut yang akhirnya menyebabkan gangguan terhadap jalannya lalu lintas. Marka parkir adalah pembatas, berupa garis utuh mengelilingi ruang parkir. Bisa berwarna kuning ataupun putih, atau garis paralel untuk garis tegak lurus atau membentuk sudut. Dengan adanya marka parkir maka kendaraan yang parkir bisa lebih teratur dan terlihat rapi., sesuai marka yang ada. Hasil observasi marka jalan yang yang rapi dan lengkap itu di jalan urip ummlharjo, disitu terlihat tatanan mobil yang rapi sesuai dengan marka jalan yang dipajang oleh dinas perhubungan. Rambu parkir adalah rambu petunjuk tempat parkir yang biasanya dilengkapi dengan papan pengumuman tambahan yang memuat informasi tentang waktu parkir, batas parkir, ketentuan tarif, penggunaan khusus tempat parkir. Hasil observasi penulis melihat rambu-rambu parkir hanya ada pada kawasan I sementara kawasan II tidak ada.
Kelengkapan juru parkir juga mempengaruhi pelayanan yang diterima oleh masyarakat pengguna parkir, contohnya rompi parkir untuk tanda pengenal bagi pengguna parkir yang ingin memarkirkan kendaraannya agar tidak salah orang, kemudian peluit yang gunanya memberikan tanda-tanda peringatan atau aba-aba pengendara disaat memarkirkan kendaraan ataupun mau mengeluarkan kendaraan. Kemudian tongkat bercahaya dan rompi berrcahaya ini sangat dibutuhkan dimalam hari, karena malam hari gelap apabila ada tongkat cahaya atau rompi bercahaya maka akan mengurangi adanya kecelakaan.

\section{Sistem Pelayanan}

Sistem perparkiran yang dipakai oleh pada parkir tepi jalan umum Kota Yogyakarta adalah sistem parkir sederhana dengan memakai karcis. Karcis diberikan kepada pengguna parkir disaat awal memarkirkan kendaraan kemudian menunjukkan kembali saat kendaraan diambil. Untuk menacapai tujuan utama dibuatnya parkir tepi jalan umum Kota Yogyakarta maka Pemerintah Kota Yogyakarta mengatur sistem izin membuka lahan parkir, izin jadi juru parkir, sistem pemungutan retribusi parkir, 
sistem bagi hasil antara dinas perhubungan dengan juru parkir, Sistem ganti rugi apabila terjadi kerusakan atau kehilangan kendaraan yang sedang parkir dalam Perda Yogyakarta No. 18 Tahun 2009 tentang Perparkiran dan Perda Kota Yogyakarta No. 19 Tahun 2009 tentang Retribusi Parkir di Tepi Jalan Umum.

Setelah dijelaskan mengenai faktor-faktor yang mempengaruhi kualitas pelayanan maka dari ke empat faktor ini yang paling utama berpengaruh terhadap kulitas pelayanan parkir tepi jalan umum Kota Yogyakarta adalah sarana dan prasarana ruang parkir (letak ruang parkir). Masalah utama yang menyebakan kualitas pelayanan parkir ini kurang baik karena banyaknya letak ruang parkir resmi yang tidak melihat dan mempedulikan kapasitas jalan raya, sehinggan hak pengguna jalan raya dan hak pejalan kaki jadi terganggu. Hal ini disebabkan karena kendaraan yang padat, meningkat tiap tahunnya sementara ruang parkir kurang. Kemudian banyaknya juru parkir (petugas parkir) lebih mengejar kepentingan pribadi daripada memberikan pelayanan kepada masyarakat. Hal ini terjadi karena kurangnya pengawasan yang dilakukan oleh dinas perhubungan. Dan alasan nya adalah yang melakukan pengawasan langsung terhadap kerja petugas parkir adalah juru pungut pada 5 wilayah parkir sementara yang lain duduk dikantor dan tidak turun ke lapangan. Namun juru pungut yang hanya 12 orang ini tidak akan maksimal melakukan pengawasan karena jumlah juru parkir 900 orang tidak sebanding dengan juru pungut dari dinas perhubungan. Dengan kurangnya pengawasan yang dilakukan oleh dinas perhubungan menyebabkan banyaknya kecurangan-kecurangn yang dilakukan oleh petugas parkir demi mengejar keuntungan pribadi.

\section{SIMPULAN}

Berdasarkan analisa dan pendalaman berbagai data yang diperoleh selama penelitian berlangsung dengan berpijak serta berlandaskan pada teori untuk menjawab permasalahan yang telah dirumuskan maka penulis mengambil kesimpulan bahwa Kualitas pelayanan parkir tepi jalan umum Kota Yogyakarta kurang baik. Letak ruang parkir tepi jalan umum yang terlalu banyak dan tidak melihat kapasitas jalan raya sering menyebabkan kemacetan. Masih banyaknya juru parkir yang tidak memberikan karcis parkir kepada pengguna parkir sementara karcis parkir adalah hak dari pengguna parkir. Tarif parkir juga tidak sesuai dengan tarif resmi. 
Faktor-faktor kualitas pelayanan parkir dimana faktor ruang parkir yang tidak bisa menampung jumlah kendaraan yang tiap tahunnya bertambah padat adalah faktor utama yang mempengaruhi kurang baiknya kualitas pelayanan parkir TJU Kota Yoyakarta. Faktor sumber daya manusia dinas perhubungan yang melakukan pengawasan langsung terhadap petugas juru parkir hanya juru pungut yang berjumlah 12 orang sementara juru parkir tepi jalan umum Kota Yogyakarta sebanyak 900 orang diluar pembantu juru parkir sehingga mereka merasa kewalahan. Sedangkan petugas dinas perhubungan yang lain hanya duduk dikantor dan menunggu laporan dari masing-masing juru pungut di lima wilayah ini. Dibalik itu semua sistem bagi hasil yang diatur dalam perda atas bargol karcis yang dipakai tidak dilaksanakan, bagi hasil dilakukan berdasarkan patokan terhadap juru parkir juga mempengaruhi kualitas pelayanan parkir, ini menyebabkan petugas parkir mengejar masukan sebanyak-banyaknya untuk memenuhi patokan yang diberiakan oleh dinas perhubungan dan mengenyampingkan tugas mereka memberikan pelayanan yang baik kepada pengguna parkir.

\section{DAFTAR PUSTAKA}

Abubakar. 1996. Мепији Lalu Lintas dan Angkutan Jalan yang Tertib. Jakarta: Direktorat Jenderal Perhubungan Darat.

Basuki, Imam dan Suwadi. 2008. Biaya Kemacetan Ruas Jalan Kota Yogyakarta. Teknik Sipil, 9(1)

Bryson, Jo. 1997. Managing Information Service: An Integrate Approuch. England: Gower

Dwiyanto, Agus. 2006. Mewujudkan Good Governance Melalui Pelayanan Publik. Cetakan ke Tiga. Gajah Mada University Press. Yogyakarta

Gaspersz, V., 1994. Manajemen Kualitas. Gramedia. Jakarta.

Haryono, Tulus. 2006. Telaah persepsi Kualitas Pelayanan Jasa Serta Penerapan Di Sektor Publik dalam Memasuki Era Reformasi, Pidato Pengukuhan Jabatan Guru Besar. Universitas Sebelas Maret. Surakarta. 23-12-2006

Hardiyansyah, 2011. Kualitas Pelayanan Publik (Konsep, Dimensi, indicator, dan Implementasinya). Cetakan ke I. Gava Media. Yogyakarta. 2003.

Moerdiono. 1992. Birokrasi dan Administrasi Pembangunan: Beberapa Pemikiran Pemecahan, Jakarta: Sinar Grafika. 
Ratminto, Winarsih.2010. Managemen Pelayanan (Penegembangan Model dan Konsep Penerapan Citizen's Charter dan Standar Pelayanan Minimal). Yogyakarta: Pustaka Pelajar

Subarsono AG. 2003. Kebijakan Publik dalam Perspektif Teoretis. Jurnal Demokrasi (Forum LSM DIY) 1(1): $1-24$

Utomo, Warsito, 1997. Peranan dan Strategi Peningkatan Pendapatan Asli Daerah (PAD) dalam Pelaksanaan Otonomi Daerah. Jurnal Ilmu Sosial dan Ilmu Politik 